\title{
Obesogenic Environment in Childhood: Implications of High Socioeconomic Level in a Developing Country
}

\section{Çocukluk Çăğında Obezojenik Çevre: Gelişmekte Olan Bir Ülkede Yüksek Sosyoekonomik Düzeyin Getirdikleri}

\section{Sibel Hatice OZUMUT $\odot$, Muferet ERGUVEN $\odot$, Esen BESLI $\odot$}

Ethics Committee Approval: This study was approved by the Goztepe Training and Research Hospital, Clinical Studies Ethics Committee, 6 March 2002, 2002/177.

Conflict of interest: The authors declare that they have no conflict of interest.

Funding: None.

Informed Consent: Informed consent was taken from the patients enrolled in this study.

\section{ABSTRACT}

Objective: Today, obesity in childhood is considered as an important health problem, especially in developed countries. This study aims to determine the prevalence of obesity in children and to reveal the relationship between television watching habit, computer use and socioeconomic status in children.

Method: $A$ cross-sectional study was performed in 11 public schools selected with random sampling in Istanbul. A total of 1479 children (767 males (51.9\%)) were included in the study. Their ages ranged from 10-15, and the mean age was $11.95 \pm 1.36$ years for girls and $12.06 \pm 1.39$ years for boys. Demographic characteristics and factors affecting obesity were inquired with the structured questionnaire form. The height, and body weights of the students were measured, and their body mass Indexes were calculated. Those with a BMI above the 95th percentile were considered obese, and those between the $85^{\text {th }}$ and $95^{\text {th }}$ percentiles were considered as overweight.

Results: In the study group, the obesity rate was calculated as 5.3\%, and the mild obesity rate as 14.9 percent. The total prevalence of overweight and obese children was $20.2 \%$. The frequency of obesity in the high socioeconomic level group was significantly higher than low one $(p<0.01)$. The average daily screen time was $3.74 \pm 1.58$ hours. The obesity risk was found to increase three times when this period exceeded five hours. In the logistic regression analysis, while high socioeconomic level was found as the main determinant among the risk factors for obesity, the effects of daily screen time were found to be marginally significant $(p<0.045)$.

Conclusion: The lifestyle of the families with high socioeconomic status is the main determinant of obesity in adolescents. Nutrition with higher calorie foods, more frequent media use and a more sedentary life brought about is an obesogenic environment created by a high socioeconomic status. Environmental risk factors for obesity should be assessed.

Keywords: Childhood obesity, socioeconomic status, daily screen time

Öz

Amac: Günümüzde özellikle gelişmiş ülkelerde çocuk yaşlardaki şişmanlık önemli bir sağlık problemi olarak ele alınmaktadır. Bu çalışma, çocuklarda obezite sıklığını belirleyebilmeyi ve çocuklarda televizyon izleme alışkanlığının, bilgisayar kullanımının ve sosyoekonomik durumun obezite ile iliskisini ortaya koymayı amaclamaktadır.

Yöntem: İstanbul'da tesadüfi örnekleme ile seçilen 11 tane devlete ait ilköğretim okulunda kesitsel bir araştırma yapıldı. Araștırmaya 767 erkek (\%51,9), 712 kız (\%48,1) olmak üzere toplam 1479

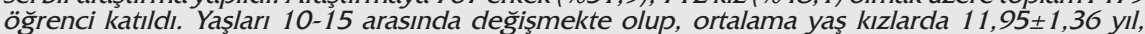

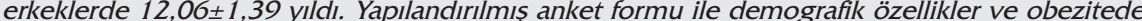
etkili olan faktörler sorgulandı. Ögrrencilerin boy ve kiloları ölcüldü ve beden kitle indeksi (BMI) hesaplandı. BMI 95. persantilin üzerinde olanlar şişman olarak, 85-95 persantilleri arası hafif şişman (overweight) olarak kabul edildi.

Bulgular: Arastırma grubunda obezite oranı \%5.3, hafif sisman oranı \%14.9 olarak saptandı. Obez ve hafif șișman toplam sıklığı \%20,2 bulundu. Sosyoekonomik düzeyin yüksek olduğu grupta obezite sıklığı kız ve erkek cinste de anlamlı yüksek olarak belirlendi $(p<0,01)$. Obezite risk faktörlerinde ana belirleyici olarak sosyoekonomik durum saptandı.

Ortalama televizyon izleme ve bilgisayar kullanma süresi 3,74 1,58 saatti. Bu sürenin 5 saatin üzerinde olduğunda obezite riskinin 3 kat arttığı saptandı. Lojistik regresyon analizinde sosyoekonomik düzey ana belirleyici olarak saptanırken, televizyon izleme ve bilgisayar kullanım süresinin obeziteye etkisi sınırda anlamlı olarak bulundu. $(p<0,045)$

Sonuç: Yüksek sosyoekonomik duruma sahip ailelerin yaşam tarzı adölesanlarda obezite için ana belirleyicidir. Daha yüksek kalorili gıdalar ile beslenme, daha cok media kullanımı ve bunun getirdiği daha sedanter yașam yüksek sosyoekonomik durumun oluşturduğu obesojenik bir çevredir. Obezite için çevresel risk faktörleri belirlenmelidir.

Anahtar kelimeler: Cocukluk çă̆ında obezite, sosyoekonomik durum, günlük medya kullanımı

(c) Copyright Istanbul Medeniyet University Faculty of Medicine. This journal is published by Logos Medical Publishing.

Licenced by Creative Commons Attribution-NonCommercial 4.0 International (CC BY-NC 4.0)
Received: 31 May 2020

Accepted: 23 July 2020

Online First: 30 September 2020

Corresponding Author: S.H. Ozumut

ORCID: 0000-0001-8023-8075

Istanbul Medeniyet University Goztepe Education and Research Hospital, Department of Pediatrics, Kadikoy, Istanbul, Turkey

sibel.ozumut@gmail.com

E. Besli

ORCID: 0000-0001-6837-5384

Istanbul Medeniyet University Medical Faculty, Goztepe Education and Research Hospital, Department of Pediatrics, Istanbul, Turkey

M. Erguven ORCID: 0000-0002-3255-1208 Abant Izzet Baysal University, Department of Pediatrics, Düzce, Turkey 


\section{INTRODUCTION}

Obesity is generally defined as a clinical condition which occurs when energy intake exceeds energy consumption, and thereby an increase in fat tissue ensues. Obesity is one of the diseases in that its prevalence increases most rapidly in all communities, and is qualified as a global epidemic by the World Health Organization ${ }^{1}$. It is a public health problem that is seen in all ages, races, ethnic groups, and many countries ${ }^{2}$. Genetic disposition as well as environmental factors such as lack of physical activity, inaccurate eating habits, and socioeconomic status (SES) have strong impact on this rapid increase $\mathrm{e}^{3,4}$.

Forty percent of overweight children in the prepubertal period continue to gain weight during adolescence, and $80 \%$ of prepubertal overweight kids and obese adolescents remain overweight and obese in adulthood ${ }^{5}$. Obesity that has onset during childhood and adolescence constitutes an increased risk for adulthood obesity. Aside from that, early diagnosis and treatment approaches become important because obesity can result in respiratory, cardiac, hormonal, orthopedic, and psychiatric disorders ${ }^{5}$. For this reason, prevalence studies have been carried out in many countries. Prevalence of overweight population was reported as $10.3 \%$ and that of obesity was found to be $6.1 \%$ in a study which involved 6924 children in the age group of 6-17 years in the Western Black Sea region of Turkey ${ }^{6}$.

There are other studies on the prevalence of obesity in various cities of Turkey ${ }^{7-9}$. Our study was carried out in Istanbul, which is considered a universe reflecting all of Turkey, and the combined population of the city is quite representative for the whole country ${ }^{10}$. This study aims at determining the obesity prevalence and risk factors related to obesity in children aged 10-15 years living in Istanbul.

\section{MATERIALS and METHOD}

This is a cross-sectional study. Eleven public schools in Istanbul were determined by random sampling method using random numbers table in this study. The required permission and the approval for gathering information on children were obtained from the Governorship of Istanbul, Kadikoy Sub-provincial Governor's Office, and the District National Education Directorate. In addition, verbal consents were obtained from the class teachers and students.

The study was planned on students attending primary school aged between 10-15 years. Collecting the study data involved two stages, namely getting the anthropometric measurements and filling the questionnaire. Demographic characteristics, eating habits, information on time spent on daily media usage, height, and weight of the children were obtained using the structured questionnaire form. In this questionnaire, socioeconomic status index developed by Kalaycioglu et al. ${ }^{11}$ and based on parents' educational levels, working status, and their assets was used. Necessary information was explained in the classes and questionnaire forms were distributed and filled in the presence of the same supervisor.

SES and daily screen time (television and computer use time) were evaluated as risk factors for obesity. Risk factors were compared among the overweight, obese and normal weight children. Weights of the children were measured using the auto-calibrated measuring scale with a sensitivity of \pm 100 gr (SECA; Vogel \& Hakle, Hamburg, Germany), which was calibrated daily at the beginning of each working day.

The measurement of height was done by using portable stadiometer in upright position with weight distributed evenly on two feet, head leaned back with no shoes on ${ }^{12}$. All of the measurements were carried out by the same person to ensure confident measurements. Body Mass Index (BMI) 
was calculated by dividing body weight $(\mathrm{kg})$ by height in square meters $\left(\mathrm{m}^{2}\right)$. The results were evaluated using age and gender adapted BMI percentile table and graphs of Centers for Disease Control (CDC). Those with a BMI of below 85 percentile were considered "normal weight" while those between 85-95 percentile were considered "overweight", and those with above 95 percentile were described as "obese" 13 .

The statistical analysis was made using the SPSS 10.0 for Windows (Inc. Chicago, IL) software package. In evaluating the data, definitive statistical methods (average, standard deviation) were used, and to compare the categorical data among the groups, chi-square test was used. Logistic regression analysis was done for multivariate analysis. The results were evaluated at the significance level of $p<0.05$ and iwithin $95 \%$ confidence interval.

\section{RESULTS}

The questionnaire was completed with 1500 children. Among them 21 participants were excluded from the study because their age group did not match on the second evaluation. Thus, a total of 1479 children were included in the study. There were 767 (51.9\%) boys and 712 (48.1\%) girls. aged between 10 to 15 years. The mean ages of female, and male participants were $11.95 \pm 1.36$, and $12.06 \pm 1.39$ years, respectively. There is no statistically significant difference between males and females as for mean ages ( $p>0.05)$.

According to the anthropometric measurements, $1180(79.8 \%)$ of the children were defined as normal, 221 (14.9\%) overweight and 78 (5.3\%) obese. The total prevalence of overweight and obese children in the sample was $20.2 \%$.

Evaluation of socioeconomic status (SES) revealed that children belonged to the low $(n=264 ; 17.8 \%)$, middle $(n=735 ; 49.2 \%)$, and high $(n=480 ; 32.4 \%)$ SES. When distribution of obesity according to so- cioeconomic status was taken into account, overweight status and obesity were detected in 11 (7.6\%) boys and 18 (15.1\%) girls in the low SES group, while these values were 93 (35.5\%) and $54(24.8 \%)$, respectively in the high SES group $(\mathrm{p}<0.001$, Table 1$)$.

Table 1. Demographic characteristics of students and distribution of risk factors.

\begin{tabular}{lllll}
\hline & \multicolumn{4}{c}{ Obesity } \\
\cline { 2 - 5 } All Students & & $\begin{array}{l}\text { None } \\
\text { n (\%) }\end{array}$ & $\begin{array}{l}\text { Present } \\
\text { n (\%) }\end{array}$ & P \\
\hline Sex & Male & $591(77.1)$ & $176(22.9)$ & \\
& Female & $589(82.7)$ & $123(17.3)$ & 0.008 \\
Socioeconomic & Low & $235(89.0)$ & $29(11.0)$ & \\
level & Moderate & $588(83.3)$ & $118(16.7)$ & \\
Daily screen & High & $333(69.4)$ & $147(30.6)$ & $<0.001$ \\
time & $<5$ hours & $914(82.4)$ & $195(17.6)$ & \\
& $\geq 5$ hours & $266(71.9)$ & $104(28.1)$ & $<0.001$ \\
& & & &
\end{tabular}

When risk factors for obesity were evaluated, high SES was defined as the most important risk factor in both univariate analysis and in logistic regression analysis. Prevalence of obesity and overweightedness were significantly higher in girls and boys with high SES than those with other socioeconomic status $(p<0.001$, Table 2$)$. In our study, $\mathbf{8 7 . 1 \%}$ of those with high SES owned personal computers, while this rate was only $6.4 \%$ in the group with low SES. The rate of using school shuttle service was $6.1 \%$ in the low SES group, while $52.3 \%$ of students in the high SES group enjoyed commuting to and from school by a private school shuttle. All of the students participated in the study consumed at least one type of food between meals. Those with high SES consumed significantly higher amounts of high-caloric foods

Table 2. Logistic Regression analysis for obesity and risk factors.

\begin{tabular}{lllllll}
\hline & & B & OR & \%95 CI & P \\
\hline Sex & Male & 0.33 & 1 & $1.07-1.82$ & 0.015 \\
& Female & & 1.39 & & \\
Socioeconomic & Low & 0.45 & 1 & $1.01-2.45$ & 0.043 \\
level & Moderate & 1.09 & 1.57 & $1.91-4.71$ & $<0.001$ \\
& High & & 2.99 & & \\
& $<5$ hours & & 1 & & \\
Daily screen time & $\geq 5$ hours & 0.30 & 1.36 & $1.01-1.82$ & $<0.043$ \\
& & & & & & \\
\hline
\end{tabular}


such as chocolate and candies compared to those with low SES $(p<0.05)$.

No significant correlation between TV watching and obesity was detected in univariate analysis in our study ( $p>0.05)$. However, when TV watching time was added to computer use time (daily screen time), it was found to be related to obesity $(p<0.001)$. The risk for obesity increased three times when this total time exceeded five hours daily (odds ratio: 3 ). In logistic regression analysis, however, daily screen time was marginally significant $(p<0.043$, Table 2$)$.

\section{DISCUSSION}

Childhood obesity has an increasing prevalence in the world, especially during adolescence; however, this prevalence varies among countries. Adolescence is the transition period from childhood to adulthood. Characteristics of this period are rapid physical growth, sexual development, and psychosocial maturation. Adolescence is a crucial period for the development of obesity and related diseases ${ }^{5,14}$. Therefore, we investigated the prevalence of obesity and associated risk factors in the adolescent population in our study.

It has been reported that the prevalence of obesity among Turkish children has risen from $6-7 \%$ to $15-16 \%$ during the last two decades ${ }^{15}$. The prevalence of obese population in the adolescent age group in our study was $5.3 \%$, which is lower than most of the European countries ${ }^{16-20}$. These marked differences in the prevalence rates for different countries may be due to different environmental, genetic, and socioeconomic factors ${ }^{6}$.

Numerous studies have evidenced the correlation between obesity and SES. These studies have indicated that prevalence of obesity in populations with low SES in the developed countries were higher, while populations with high SES in the developing countries had higher prevalence of obesity ${ }^{18,20-23}$. Similar results were reported by
McLaren in a review of 333 published studies, in which relationship between SES and obesity was investigated $^{24}$. Moreover, similar results were found in some national studies that were carried out on this subject ${ }^{7,8}$. In the "Project of Growth Monitoring in School Age (6-10 years) Children in Turkey" included 12301 children from 140 primary schools and carried out with the support of the Ministry of Health ${ }^{25}$. The prevalence of obesity was found to be higher in the high SES group, and this result was similar to that of our study. Considering that Turkey is a developing country, high prevalence of obesity in families with high SES is consistent with the literature. This situation can be regarded as a negative consequence brought out by a rapid socioeconomic transition in developing countries.

Watching television and computer use are reported among the risk factors for obesity. These can lead to obesity via many ways such as decreasing physical activity, deteriorating sleeping pattern, and promoting unhealthy dieatry habits and consumption of high-calorie products ${ }^{26}$. In a study conducted by Reilly et al., the analysis of 8000 Scottish children revealed that watching television more than eight hours a week at age three correlates with an increase in obesity risk at the age of seven ${ }^{27}$. Many studies have also showed the presence of a positive linear correlation between intense television watching and $\mathrm{BMI}^{28,29}$. In our study, contrary to the results of these previous data, television watching time alone was not found as a significant risk factor for obesity. One of the reasons for this is that the child who has no private room can carry out another activity while watching television in the living room where television is placed. It is thought that children might watch television for longer periods of time while performing synchronous physical activities. However, when television watching time is evaluated with the added computer use time (daily screen time), it was found that five or more hours of daily screen time increased the risk of obesity by about three times. This may have two different explana- 
tions. Computer use necessitates the child to sit in front of the screen and focus on it personally. Thus, it seems like computer use is responsible for diminishing the physical activity of the child and leading to a sedentary life. Another reason might be that $87.1 \%$ of the families with high SES own computers, while this rate is only $6.4 \%$ for the kids in the other SES groups. In order to determine which risk factor (computer use or high SES) is more effective, logistic regression analysis was applied, and it was found that high SES was a major determinant while media use was marginally significant.

High socioeconomic level provides greater number of technologic opportunities for the child to possess or has access to. In our study, high income of families paralleled with the amount and the variety of the food the families provided to their children. In addition, most of the children in the low SES group walked to and from the school, while this rate was markedly lower in children of the families with higher SES. When these data were evaluated together: children of the high SES families used school shuttle services for commuting to school, sat in their rooms, spent time with computers, and fed on high caloric foods. As a result, overeating and intense media use that results in diminished physical activity can explain the three-fold increase in obesity among the children of high SES families.

\section{Study strengths}

Our study was carried out in Istanbul, which is considered a universe reflecting all of Turkey. The combined population of the city is quite representative for the whole country. Data of 1479 children is the highest number among the similar studies previously performed in Istanbul.

\section{Study limitations}

There are some limitations of this study due to its cross-sectional design. Since cause-effect relationship was evaluated simultaneously, it was unknown whether the risk factors causing obesity in these children were preexisted or not. It is hard to say that factors causing obesity existed before the results of the study were obtained.

\section{CONCLUSION}

Obesity is a serious health problem seen in increasing frequency in childhood. It develops in families with higher SES and environmental stresses such as too much calorie intake and lack of physical activity also contribute to its development. It is intended to underline that especially in developing countries like Turkey, life styles of the families with high SES constitute an obesogenic environment. Environmental risk factors for obesity should be assessed taking national circumstances into account, and the results obtained should guide the type and the extent of necessary precautions as well as an appropriate action plan.

Acknowledgement: I am grateful to Professor Dr. Nadi Bakırcl, the Head of the Department of Public Health at Acrbadem University, for his contribution to data analysis.

\section{REFERENCES}

1. WHO. Obesity Preventing and Managing the Global Epidemic. Report of a WHO Consultation. WHO Technical Report Series 894. Geneva: World Health Organization 2000. Available from: https://apps.who.int/iris/ handle/10665/42330.

2. Guthold R, Cowan MJ, Autenrieth CS, Kahn L, Riley LM. Physical activity and sedentary behavior among schoolchildren: a 34-country comparison. J Pediatr. 2010;157:43-9. [CrossRef]

3. Hill JO, Peters JC. Environmental contributions to the obesity epidemic. Science. 1998;280:1371-4. [CrossRef]

4. Farooqi IS, O'Rahilly S. Recent advances in the genetics of severe childhood obesity. Arch Dis Child. 2000;83:31-4. [CrossRef]

5. Sahoo K, Sahoo B, Choudhury AK, Sofi NY, Kumar R, BhadoriaAS. Childhood obesity: causes and consequences. J Family Med Prim Care. 2015;4:187-92. [CrossRef]

6. Simsek E, Akpinar S, Bahcebasi T, Senses DA, Kocabay K. The prevalence of overweight and obese children aged 6-17 years in the West Black Sea region of Turkey. Int J Clin Pract 2008;62:1033-8. [CrossRef]

7. Akac H, Babaoglu K, Hatun S, Aydogan M, Turker G, Gokalp AS. Obesity prevalence and risk factors of schoolaged children in Kocaeli region. J Child. 2002;2:29-32.

8. Ozturk A, Akturk S. Obesity prevalence and associated risk factors in school-aged children. TAF Prev Med Bull. 
2011:10:53-60. [CrossRef]

9. Savaşhan Ç, Sarı O, Aydoğan Ü, Erdal M. Obesity frequency in school children and related risk factors. Turkish Journal of Family Practice. 2015;19:14-21. [CrossRef]

10. Bundak R, Furman A, Gunoz H, Darendeliler F, Baş F, Neyzi O. Body mass index references for Turkish children. Acta Pediatr. 2006;95:194-8. [CrossRef]

11. Kalaycioglu S. Kardam F, Tüzün S, Ulusoy M. Approach and Attempts to develop a measure of socio-economic status for Turkey. Society and Doctor. 1988;13;123-5.

12. Cole TJ, Bellizi MC, Flegal KM, Dietz WH. Establishing a Standard Definition for Child Overweight and Obesity Worldwide: International Survey. BMJ. 2000;39:129-35. [CrossRef]

13. CDC Growth Charts: United States. From vital and health statistics of the Centers for Disease Control and Prevention, National Centers for Health Statistics. Advance Data. 2000; 314. Available from: http://www.cdc.gov/growthcharts

14. Berberoğlu $M$. Obesity in adolescents. Adolescent Health. 2008;63:79-80.

15. Obesity prevention and control program of Turkey (2010-2014). Ministry of Health of Turkey. General Directorate of Primary Health Care. Ankara, Turkey, 2010. Available from: http://beslenme.gov.tr/content/files/ home/obesity_prevention_and_control_program_of_ turkey_2010_2014.pdf

16. Brettschneidera A, Rosario A, Kuhnert R et al. Updated prevalence rates of overweight and obesity in 11 - to 17 year-old adolescents in Germany. Results from the telephone-based KiGGS Wave 1 after correction for bias in self-reports. BMC Public Health. 2015;15:1101. [CrossRef]

17. Sanchez-Cruz J, Jimenez-Moleon J, Fernandez-Quesada F, Sanchez M. Prevalence of Child and Youth Obesity in Spain in 2012. Rev Esp Cardiol (Eng Ed) 2013;66:371-6. [CrossRef]

18. Lobstein TJ, James WPT, Cole TJ. Increasing levels of excess weight among children in England. Int J Obes Relat Metab Disord. 2003;27:1136-8. [CrossRef]

19. Kirchengast S, Schoberb E. Obesity among female adolescents in Vienna, Austria-the impact of childhood weight status and ethnicity. BJOG. 2006;113:1188-4. [CrossRef]
20. Spinellia A, Buoncristianob M, Kovacsc V. et al. Prevalence of Severe Obesity among Primary School Children in 21 European Countries. Obes Facts. 2019;12:244-58. [CrossRef]

21. Wang Y. Croos-national comparison of childhood obesity: the epidemic and the relationship between obesity and socioeconomic status. Int. J. Epidemiol. 2001;30:112936. [CrossRef]

22. Janssen I, Boyce Wf, Simpson K, Pickett W. Influence of individual and area-level measures of socioeconomic status on obesity, unhealthy eating and physical in activity in Canadian adolescents. Am J Clin Nutr. 2006;83:139-45. [CrossRef]

23. Wang Y, Lim H. The global childhood obesity epidemic and the association between socio-economic status and childhood obesity. Int Rev Psychiatry. 2012;24:176-88. [CrossRef]

24. McLaren L. Socioeconomic Status and Obesity. Epidemiol Rev. 2007;29:29-48. [CrossRef]

25. Research Report of Growth Monitoring among School Age Children (6-10 age group) in Turkey (TOÇBi) Project Ministry of Health of Turkey, General Directorate of Primary Health Care, Hacettepe University Faculty of Health Sciences, Department of Nutrition and Dietetics, Ministry of Education of Turkey. Ministry of Health Publication number: 834, Ankara, 2011. Available from: http:// beslenme.gov.tr/content/files/yayinlar/kitaplar/diger_kitaplar/tocbi_kitap.pdf

26. Council on Communications and Media, Strasburger VC. Children, adolescents, obesity, and the media [published correction appears in Pediatrics. Pediatrics. 2011;128:201-8. [CrossRef]

27. Reilly JJ, Armstrong J, Dorosty AR. et al; Avon Longitudinal Study of Parents and Children Study Team. Early life risk factors for obesity in childhood: cohort study. BMJ. 2005;330:1357. [CrossRef]

28. Strasburger VC, Wilson BJ, Jordan AB. Children, Adolescents and the Media. California. $2^{\text {nd }}$ ed., SAGE Publications, Thousand Oaks, 2009.

29. Sigman A. Time for a view on screen time. Arch dis child. 2012;97:935-42. [CrossRef] 